\title{
INTERNATIONAL LABOUR LAW STANDARDS CONCERNING COLLECTIVE BARgaINING IN PUBLIC ESSENTIAL SERVICES
}

\section{Giuseppe Carabetta*}

Labour standards adopted under the auspices of the ILO constitute the principal international influences on public sector collective bargaining; it is those standards that are the subject of this article. Focusing on the position of essential public sector employees, ILO principles concerning collective bargaining, dispute settlement and the right of workers to withdraw their services as part of bargaining are examined. Particular attention is devoted to the application of ILO standards to essential public sector employees and police officers; and the extent to which Australian law complies with these standards. The ILO supervisory bodies have acknowledged that restrictions on the general right of workers to collectively bargain and to strike can be justified in the case of essential public employees, but only on a minimal or proportional analysis. The ILO has also emphasised that any restrictions on the right to strike must be compensated by adequate, impartial and speedy conciliation and arbitration processes. It is shown, however, that with respect to essential public employees and police officers operating under the Fair Work Act 2009 (Cth), Australian law falls short on both of these scores, with a resultant uncertainty regarding the right of these workers to bargain collectively.

\section{INTRODUCTION}

One of the core objectives of the International Labour Organisation (ILO) is to promote collective bargaining worldwide. This objective was stated in 1944 in the Declaration of Philadelphia, which is annexed to the ILO Constitution and recognises 'the solemn obligation of the International Labour Organisation to

\footnotetext{
* Senior Lecturer, University of Sydney. The author is grateful to the Deakin Law Review's anonymous referees for their helpful suggestions and to Mikaela Jenkins and Ryan Hunter for their research assistance. Of course, responsibility for any errors or omissions in the article rests with the author alone.
} 
further among the nations of the world programmes which will achieve ... the effective recognition of the right of collective bargaining'. ${ }^{1}$ This nearly universally accepted principle is embodied in the ILO's Right to Organise and Collective Bargaining Convention, 1949 (No 98), ${ }^{2}$ and guarantees to all workers, including public sector workers, the rights to organise and bargain collectively. ${ }^{3}$ In June 1998, the ILO took a further step towards the goal by adopting the Declaration of Fundamental Principles and Rights at Work ('the Declaration'). ${ }^{4}$ The Declaration provides that:

The International Labour Conference ... [d] eclares that all Members, even if they have not ratified the [core ILO Conventions] ${ }^{5}$, have an obligation arising from the very fact of membership in the Organization to respect, to promote and to realize, in good faith and in accordance with the Constitution, the principles concerning the fundamental rights which are the subject of those Conventions, namely ... freedom of association and the effective recognition of the right to collective bargaining. ${ }^{6}$

If collective bargaining is to be effective and sustainable the framework in which it takes place must be based on the principles of the independence and autonomy of the parties, and 'voluntary and free collective bargaining',

\footnotetext{
* Senior Lecturer, University of Sydney. The author is grateful to the Deakin Law Review's anonymous referees for their helpful suggestions and to Mikaela Jenkins and Ryan Hunter for their research assistance. Of course, responsibility for any errors or omissions in the article rests with the author alone.

${ }^{1}$ International Labour Organisation ('ILO'), Convention concerning the Promotion of Collective Bargaining (ILO Convention 154), opened for signature 3 June 1981, 1331 UNTS 267 (entered into force 11 August 1983) preamble, para 3.

2 ILO, Right to Organise and Collective Bargaining Convention 1949, opened for signature 1 July 1949, 96 UNTS 257 (entered into force generally 18 July 1951; entered into force for Australia 28 February 1973) arts 3-4 ('Convention No 98').

${ }^{3}$ Internationally, Convention No 98 is one of the most widely ratified Conventions (currently 161 ratifications): see ILO, Collective Bargaining in the Public Service: A Way Forward (Report No III (Part 1B), International Labour Conference $-102^{\text {nd }}$ Session, 2013) <http://www.ilo.org/wcmsp5/groups/public/---ed_norm/---relconf/documents/meeting document/wcms_205518.pdf> ('Collective Bargaining in the Public Service'). It will be noted presently however that the application of Convention No. 98 in the public services remains controversial in many member states.

${ }^{4}$ ILO, Declaration on Fundamental Principles and Rights at Work, ILO Doc CIT/1998/PR20A (19 June 1998). The Declaration is binding on Australia by virtue of its membership to the ILO.

5 There are eight such Conventions; among them: Convention concerning Freedom of Association and Protection of the Right to Organise (ILO Convention 87), opened for signature 9 July 1948, 68 UNTS 17 (entered into force 4 July 1950) and International Labour Organisation, Right to Organise and Collective Bargaining Convention 1949, above n 2.

${ }^{6}$ ILO, Declaration on Fundamental Principles and Rights at Work, above n 4, art 2.

${ }^{7}$ Bernard Gernigon, Alberto Odero and Horacio Guido, Collective Bargaining: ILO Standards and the Principles of the Supervisory Bodies (2000), International Labour Organisation, 27
} 
leaving it to the parties to reach their own negotiated settlements. Furthermore, the ILO's supervisory bodies have stated that although certain rules and practices - such as mediation and conciliation procedures - can facilitate and promote collective bargaining, all legislation establishing machineries and procedures designed to facilitate bargaining and settle collective bargaining disputes between the social partners must respect the autonomy of the parties. ${ }^{8}$

Restrictions on or the removal of the general right of workers to strike in support of collective bargaining and its substitution by compulsory arbitration can be justified but only on a minimal or proportional analysis. Even in the context of the public emergency services, including the police services, the ILO has noted that the question of the right to strike in many countries is now less of a 'yes or no issue', and that blanket prohibition of strikes is less frequent than in the past. ${ }^{9}$ Nonetheless, despite 'long debates and much experience', ${ }^{10}$ the question of essential and emergency service employees' freedom to strike in support of collective bargaining remains controversial, and the need to balance this right with the necessity to protect the community from danger to life, health, and safety ${ }^{11}$ is very much a live issue.

This paper examines the ILO principles of collective bargaining for essential public service employees as these principles emerge from the various Conventions and Recommendations of the ILO and the commentary of its supervisory bodies. ${ }^{12}$ The first section reviews the core ILO Conventions that protect the collective bargaining rights of workers, including public sector workers. Thereafter, the paper considers international labour standards concerning collective bargaining, dispute settlement and the right of unionised public sector employees to withdraw their services as part of bargaining. Particular attention is devoted to ILO standards concerning essential public sector employees and police officers, a topic that has remained largely at the

\footnotetext{
<http://www.ilo.org/wcmsp5/groups/public/---ed_norm/---normes/documents/publication /wcms_087931.pdf>.

${ }^{8}$ ILO, Collective Bargaining in the Public Service: A Way Forward, above n 3, 187 [389], referring to the ILO's Committee of Freedom of Association. As noted below (see text accompanying notes 69-70), the Committee of Experts on the Application of Conventions and Recommendations has made comments to the same effect.

${ }^{9}$ International Labour Organisation, Public Emergency Services: Social Dialogue in a Changing Environment (January 2003) $101 \quad<$ http://www.ilo.org/public/libdoc/ilo/2002 /102B09_313_engl.pdf> (Public Emergency Services).

${ }^{10}$ Ibid 100.

${ }^{11}$ This represents the ILO's 'threshold' test in determining whether or when the rights of essential services workers to bargain and to strike can be limited or even prohibited.

${ }^{12}$ Namely, the Committee of Experts on the Application of Conventions and Recommendations and the Committee on Freedom of Association.
} 
fringe of labour law literature. Finally, focusing on the position of essential public employees and police officers under the Australian labour relations system, the article examines the degree to which Australian law complies with ILO standards.

\section{Public Sector Collective Bargaining and the FUNDAMENTAL ILO FREEDOM OF ASSOCIATION Conventions}

The core ILO Conventions that protect the collective bargaining rights of all workers, including public sector employees, are the Right to Organise and Collective Bargaining Convention, 1949 (No 98) ('Convention No 98'), ${ }^{13}$ and the Freedom of Association and Protection of the Right to Organise Convention, 1948 (No 87) ('Convention No 87'). ${ }^{14}$ These Conventions are often described as the cornerstone documents in international labour law on freedom of association, establishing the architecture for this right. Australia has ratified each of the Conventions; ${ }^{15}$ and the principles underlying them are also encapsulated in the Declaration. ${ }^{16}$ In addition, all public sector employees, with certain exceptions as discussed below, are covered by the Labour Relations (Public Service) Convention, 1978 (No 151) ('Convention No 151'), ${ }^{17}$ and the Collective Bargaining Convention, 1981 (No 154) ('Convention No 154'). ${ }^{18}$

Convention No 98, adopted by the ILO to supplement certain aspects of Convention No 87, has three central objectives. These are (i) the protection of workers against anti-union discrimination; (ii) protection against interference with the internal affairs of workers' and employers' representative organisations; and (iii) the promotion of collective bargaining. ${ }^{19}$ Importantly, Convention No 98 has since been supplemented by Convention No 151 and by Convention No 154, the latter of which extends the right to collective

\footnotetext{
${ }^{13}$ ILO, Right to Organise and Collective Bargaining Convention 1949, above n 2.

${ }^{14}$ ILO, Convention concerning Freedom of Association and Protection of the Right to Organise (ILO Convention 87), opened for signature 9 July 1948, 68 UNTS 17 (entered into force 4 July 1950).

${ }^{15}$ Rosemary Owens, Joellen Riley and Jill Murray, The Law of Work (Oxford University Press, $2^{\text {nd }}$ ed, 2011) 533. Australia ratified the Conventions on 28 February 1973.

${ }^{16}$ ILO, Declaration on Fundamental Principles and Rights at Work, above n 4.

17 ILO, Labour Relations (Public Service) Convention (ILO Convention 151), opened for signature 7 June 1978, 1218 UNTS 87 (entered into force 25 February 1981).

${ }^{18}$ ILO, Convention concerning the Promotion of Collective Bargaining, above $\mathrm{n} 1$.

${ }^{19}$ ILO, Collective Bargaining in the Public Service: A Way Forward, above n 3, 75.
} 
bargaining to all employees in public administration..$^{20}$ A state which ratifies Convention No 154 is obligated to promote collective bargaining in both the private and public sector, and allows only to the public sector the fixing of special modalities of application of the Convention by national laws or practice. ${ }^{21}$ Convention No 151 also provides protection to public employees against acts of anti-union discrimination and interference by public authorities, essential to the right to organise and freedom of association. By extension, it protects collective bargaining. ${ }^{22}$

The relationship between these instruments and the ILO's fundamental standards on freedom of association and collective bargaining is clear. In its recent General Survey on collective bargaining rights in the public service, ${ }^{23}$ the Committee of Experts noted that it had repeatedly highlighted the connection between promotion of the right to organise and to bargain collectively, and the development of human potential, economic growth, social justice and sustainable relationships. It had also highlighted the relevance of this right to achieving the objective of 'decent work'. The Committee further noted that it had highlighted these matters 'particularly during times of economic crisis'. ${ }^{24}$

All of the above Conventions allow member states to determine whether, and to what extent, their guarantees apply to 'the armed forces and the police'. ${ }^{25}$ There are two important observations to be made here. The first is that, although these provisions allow for the possible exclusion of police, they are clearly not binding on member states. Second, in Australia, as elsewhere, police officers are subject to the same labour relations systems that are applicable to other

\footnotetext{
${ }^{20}$ See art 1 of Convention No 151 and Convention No 154. Convention No 98 excluded from its scope public sector employees engaged in the administration of the state.

${ }^{21}$ Gernigon, Odero and Guido, above n 7, 47.

${ }^{22}$ ILO, Collective Bargaining in the Public Service: A Way Forward, above n 3, 75; ILO, Public Emergency Services, above n 9, 92.

${ }^{23}$ ILO, Collective Bargaining in the Public Service: A Way Forward, above n 3, 6. See further, International Labour Organisation, Manual on Collective Bargaining and Dispute Resolution in the Public Service (2011) <http://www.ilo.org/sector/Resources/training-materials/WCMS_ 180600/lang--en/index.htm> (Manual on Collective Bargaining).

${ }^{24}$ ILO, Collective Bargaining in the Public Service: A Way Forward, above n 3, 6.

${ }^{25}$ ILO, Convention concerning Freedom of Association and Protection of the Right to Organise (ILO Convention 87), above 14, art 9; ILO, Right to Organise and Collective Bargaining Convention 1949, above n 2, art 5; ILO, Labour Relations (Public Service) Convention (ILO Convention 151), above 17, art 1; ILO, Convention concerning the Promotion of Collective Bargaining, above n 1, art 1. The Conventions include a similar type of exclusion provision for those public sector workers directly engaged in the administration of the state and those in highlevel or confidential provisions.
} 
employees. ${ }^{26}$ Thus, as will be seen, for police members operating under Australia's current national labour relations system, the bargaining regime makes no distinction between police officers and other employees. ${ }^{27}$ It can therefore be assumed that the guarantees concerning collective bargaining applicable to public sector employees apply equally to police officers. ${ }^{28}$

\section{INTERNATIONAL STANDARDS CONCERNING Collective Bargaining}

The right of trade unions and workers' organisations to bargain freely with employers is reflected in article 4 of Convention No 98, which provides that measures shall be taken to promote voluntary negotiation between the parties and their organisations, with a view to the regulation of employment conditions by means of collective agreements. According to the Committee on Freedom of Association, the voluntary negotiation of collective agreements, and the autonomy of the bargaining parties, constitute essential elements of freedom of association, and trade unions should have the right, through collective bargaining, to seek to improve the employment conditions of those they represent. ${ }^{29}$

The Committee has stated that nothing in article 4 places a duty on a government to enforce collective bargaining by compulsory means with a given organisation, and that such interference would clearly alter the nature of

${ }^{26}$ See Giuseppe Carabetta, 'Police Bargaining Disputes and Third-Party Intervention in Australia: Which Way Forward?’ (2013) 18(1) Deakin Law Review 67, nn 11, 13. While Australia is among only a minority of countries that grants police officers full industrial rights enjoyed by other workers (see ILO, Public Emergency Services, above n 9, 95-6), the Committee of Experts has recently acknowledged that in a significant number of member countries legislation implementing Convention No. 151 also applies to police officers: ILO, Collective Bargaining in the Public Service: A Way Forward, above n 3.

${ }^{27}$ The only modification to this scheme for police is in relation to the exclusion from bargaining of certain operational matters: see Giuseppe Carabetta, 'Fair Work and the Future of Police Industrial Regulation in Australia' (2011) 24(3) Australian Journal of Labour Law 260 ('Fair Work').

${ }^{28}$ A similar approach has been applied in other contexts. See, for example, Re an Interest Arbitration between the Durham Regional Police Association and the Regional Municipality of Durham Police Services Board (Preliminary Award, Paula Knopf, 13 July 2007) [76] <http://www.policearbitration.on.ca/content/stellent/groups/public/@abcs/@www/@opac/doc uments/awards/07-008.pdf>.

${ }^{29}$ International Labour Organisation, Freedom of Association - Digest of Decisions and Principles of the Freedom of Association Committee of the Governing Body of the ILO (November 2006) International Labour Organisation, [925] <http://www.ilo.org/wcmsp5 /groups/public/---ed_norm/---normes/documents/publication/wcms_090632.pdf> ('Freedom of Association — 2006 Digest'). 
bargaining. ${ }^{30}$ Collective bargaining, if it is to achieve its objectives, must be voluntary and not entail recourse to compulsion. ${ }^{31}$ Accordingly, public authorities are required to refrain from any interference which would restrict workers' rights to bargain freely, except in compelling and justifiable circumstances. ${ }^{32}$ Thus, the supervisory bodies have accepted the imposition of certain sanctions in the case of bargaining conduct which is contrary to good faith principles, but only where such sanctions are not disproportionate. ${ }^{33}$

As will be explained in under heading IV below, the supervisory bodies have emphasised that third party machinery in support of bargaining, ${ }^{34}$ should also be voluntary in nature and accepted by the parties. The Committee of Experts appointed by the ILO's Governing Body has stressed that legal systems providing (for example) for conciliation and mediation by a ministerial body once a specified period in the bargaining process has expired, and without a request from either party, are not, in principle, in conformity with this standard. ${ }^{35}$ The Committee has further emphasised that while systems enshrining voluntary arbitration are allowable, compulsory arbitration is allowable only in certain exceptional cases, such as in the public sector if negotiations have failed and conciliation and/or mediation procedures have been exhausted, or, as seen below, in the context of truly essential public services. ${ }^{36}$

\footnotetext{
${ }^{30}$ Ibid [927].

${ }^{31}$ Ibid [926]-[927]. Following this general approach, it cannot therefore be deduced from the ILO's principles on collective bargaining that there is any formal obligation to negotiate or form an agreement, although such an obligation is imposed in certain legal systems: Gernigon, Odero and Guido, above n 7, 41, n 5.

32 International Labour Organisation, Freedom of Association - 2006 Digest, above n 29, [881], [994], [1024]-[1042].

${ }^{33}$ Gernigon, Odero and Guido, above n 7, 41. For example, when examining in one case legislation which provided that the employer was obliged to pay workers for days they had been on strike, in cases where the strike had occurred because the employer had not responded to the demands and because conciliation had been abandoned, the Committee on Freedom of Association considered that the sanctions were disproportionate: ibid.

${ }^{34}$ Notably, conciliation, mediation and arbitration.

35 The Committee notes that such systems involve administrative or judicial intervention that has not been requested by the parties, which 'opens the door to potential interference or pressure on one or other of the parties, depending on the Government's political stance.': ILO, Collective Bargaining in the Public Service: A Way Forward, above n 3, 172.

${ }^{36}$ Ibid 172.
} 


\section{A Principles Concerning Public Sector Bargaining}

The ILO, through its conventions and recommendations and the work of its supervisory bodies, notably the Committee of Experts and Committee on Freedom of Association, has established the following principles pertaining to public sector collective bargaining:

1. As part of the positive duty upon Member States to promote the principles of freedom of association, all employees of public undertakings and autonomous public institutions must have a right to collective bargaining. ${ }^{37}$ However, as mentioned above, a Member State is entitled to exclude certain groups of public sector employees namely police officers and members of the armed forces, public sector workers engaged directly in the administration of the state, and those in high-level positions or whose work involves confidential information — although these exclusions are clearly optional for Member States. ${ }^{38}$

2. Public sector employees are to enjoy the same civil and political rights as other workers, rights that are fundamental to the normal exercise of freedom of association. Their enjoyment is subject only to those justifiable restrictions pertinent to the public sector status of the worker and the nature of the worker's functions. ${ }^{39}$

3. The imposition of compulsory arbitration (at the initiative of the authorities, or one of the parties, or by law) is an exception to the fundamental right of public sector workers, embodied in the respective ILO Conventions and outlined above, to engage in free and voluntary collective bargaining. ${ }^{40}$ Compulsory arbitration is considered '[o]ne of the most radical forms of intervention by the authorities in collective bargaining'. ${ }^{41}$

4. Restrictions on, or the removal of, the general right of public sector workers to collective bargaining, and its substitution by compulsory

\footnotetext{
${ }^{37}$ Ibid [885]-[903].

${ }^{38}$ See text accompanying n 22.

${ }^{39}$ Michael Lynk, Expert Affidavit on Essential Services (9 February 2012) Law of Work, 7-8 $<$ http://lawofwork.ca/wp-content/uploads/2012/02/Lynk-Expert.pdf >, referring to art 9 of Convention No 151.

${ }^{40}$ ILO, Freedom of Association - 2006 Digest, above n 29, [992]-[994].

${ }^{41}$ Gernigon, Odero and Guido, above n 7, 44, quoted in Lynk, above n 39, 8.
} 
arbitration, can only be justified (other than in certain temporary situations $)^{42}$ in the following circumstances:

- $\quad$ where the employees are police officers and members of the armed forces, public sector workers engaged directly in the administration of the state, and those engaged in high-level or confidential positions; or

- $\quad$ where the employees are engaged in ' essential services' within the strict meaning of the term (see below).

Arbitration which is voluntary — that is, accepted by both parties - is always allowable. ${ }^{43}$

5. To comply with the general right of public sector employees to collective bargaining, the term 'essential services' is to be given a strict and purposive meaning. Essential services are those 'the interruption of which would endanger the life, personal safety or health of the whole of part of the population'. ${ }^{44}$ A broader or more elastic definition of essential services would be incompatible with the fundamental right of public sector employees to collective bargaining. ${ }^{45}$

6. In order to gain and retain the parties' confidence in collective bargaining, any compulsory arbitration system should be truly independent and its outcomes should not be predetermined by legislative requirements. ${ }^{46}$

\section{B Special Characteristics of Public Service}

Aside from the above principles, there are a number of additional standards stemming from the special characteristics of public service. These special characteristics, which raise specific problems for public sector bargaining, are outlined in a leading study by Bernard Gernigon, Alberto Odero and Horacio Guido. ${ }^{47}$ First, public servants are often subject to one or more sets of uniform conditions of service. These contain exhaustive regulations covering the rights

\footnotetext{
${ }^{42}$ See under heading IV, below.

${ }^{43}$ Gernigon, Odero and Guido, above n 7, 52.

${ }^{44}$ ILO, Freedom of Association - 2006 Digest, above n 29, [994].

${ }^{45}$ Lynk, above n 39, 8.

${ }^{46}$ Ibid, referring to the ILO, Freedom of Association - 2006 Digest, above n 29, [995].

${ }^{47}$ Gernigon, Odero and Guido, above n 7, 48-50. For a detailed discussion of these special features of public service that can create difficulties for collective bargaining, see ILO, Collective Bargaining in the Public Service: A Way Forward, above n 3, 78-9.
} 
and obligations of the employees, thereby leaving little room for negotiation. This is certainly the case in the essential public services sector, ${ }^{48}$ particularly in police services where an exhaustive 'code' of regulations characteristically covers, inter alia, conditions of service. ${ }^{49}$

A further difficulty is that many management decisions concerning the pay and employment conditions of public employees are determined by a political process in which budgetary questions are decided by parliament, and affected interest groups try to influence outcomes. ${ }^{50}$ These bodies are not always the direct employers, and their decisions must take the financial situation of the country and the general public interest into account. Moreover, the duration of collective agreements does not always coincide with the budgetary cycle, which can cause further difficulties. ${ }^{51}$

These problems are compounded by other issues such as the determination of negotiating parties at different levels of government, as well as problems in defining the scope of collective bargaining in a public sector context. ${ }^{52}$ The latter poses particular difficulties in a policing context when it is necessary to distinguish between operational matters, such as decisions relating to the deployment of officers, and matters pertaining to working conditions, such as occupational health and safety. ${ }^{53}$ The ILO points out that in order to avoid such problems, laws and regulations applying to public services in many countries prohibit bargaining on certain aspects of public service. ${ }^{54}$

Because of these issues, and so that account can be taken of different national systems and procedures, both Convention No 151 and Convention No 154 allow for 'special modalities' of application for collective bargaining in the public service. These modalities might be fixed by national laws or regulations. ${ }^{55}$ According to the ILO, such modalities could include:

\footnotetext{
48 ILO, Public Emergency Services, above n 9, 99.

${ }^{49}$ Carabetta, Fair Work, above n 27, 1.

50 ILO, Manual on Collective Bargaining, above n 23, 50; ILO, Collective Bargaining in the Public Service: A Way Forward, above n 3, 119; ILO, Public Emergency Services, above n 9, 99.

51 Gernigon, Odero and Guido, above n 7, 48.

52 ILO, Manual on Collective Bargaining, above n 23.

53 ILO, Public Emergency Services, above n 9, 98-9. The ILO itself cites, as an example, the decision as to the 'number of personnel assigned to a fire truck or police [patrol] car', arguing that it not clear whether this is a policy matter or an employment matter.

54 Ibid 99.

55 ILO, Labour Relations (Public Service) Convention (ILO Convention 151), above 17, art 7; ILO, Convention concerning the Promotion of Collective Bargaining, above $\mathrm{n} 1$, art 1(3).
} 
- $\quad$ parliament or the competent budgetary authority setting upper or lower limits for wage negotiations, or establishing an overall budgetary package within which parties may negotiate monetary or standard-setting clauses;

- legislative provisions giving the financial authorities the right to participate in collective bargaining alongside the direct employer;

- harmonisation of an agreed bargaining system with a statutory framework ... ; [and]

- the initial determination by the legislative authority of directives regarding the subjects that can be negotiated, at what levels collective bargaining should take place or who the negotiating parties may be. The determination of directives should be preceded by consultations with the organisations of public servants. ${ }^{56}$

In relation to the first of these special modalities, ${ }^{57}$ the Committee of Experts has stated that where Parliament or the budgetary authority establishes such limits or an overall budget package for bargaining negotiations, they must nonetheless 'leave a significant role to collective bargaining'. Moreover, it is essential that 'workers and their organizations be able to participate fully and meaningfully in designing this overall bargaining framework' ${ }^{58}$ This implies in particular that 'they must have access to all the financial, budgetary and other data required, in a transparent manner' ${ }^{59}$

The Committee of Freedom of Association has similarly stated that:

\footnotetext{
${ }^{56}$ ILO, Manual on Collective Bargaining, above n 23, 50, drawing on Shauna Olney and Marleen Rueda, Convention No 154: Promoting Collective Bargaining (2005) International Labour Organisation, $14<$ http://library.fes.de/pdf-files/gurn/00349.pdf >.

${ }^{57}$ This modality has, especially in the context of the recent financial crisis, hitherto been the main focus of the ILO's supervisory bodies.

${ }^{58}$ ILO, Freedom of Association and Collective Bargaining, (Report No 3, International Labour Conference - 81st Session, 1994) [263] <http://www.ilo.org/public/libdoc/ilo/P/09661/ 09661(1994-81-4B).pdf> ('Freedom of Association'), quoted in Gernigon, Odero and Guido, above $\mathrm{n}$ 7, 49 (emphasis in original).

${ }^{59}$ Ibid [263]; ILO, Collective Bargaining in the Public Service: A Way Forward, above n 3, 121. This is not, however, the case of legislative provisions which, on grounds of economic stabilisation, impose a specific percentage increase, thus ruling out any possibility of bargaining. During periods of prolonged and widespread economic stagnation the Committee of Experts requires that the authorities 'should give preference as far as possible to collective bargaining ...; where the circumstances rule this out, measures of this kind should be limited in time and protect the standard of living of the workers most affected...[and thus] reach a fair and reasonable compromise between the need to preserve as far as possible the autonomy of the parties and [budgetary difficulties]': ILO, Freedom of Association [264].
} 
In so far as the income of public enterprises and bodies depends on state budgets, it would not be objectionable — after wide discussion and consultation between the concerned employers' and employees' organizations in a system having the confidence of the parties - for wage ceilings to be fixed in state budgetary laws, and neither would it be a matter for criticism that the Ministry of Finance prepare a report prior to the commencement of collective bargaining with a view to ensuring respect of such ceilings. ${ }^{60}$

It is important to note that before ceilings are established, provision must be made to ensure that the employers' and employees' organisations be consulted and be able to express their points of view to the authority for assessing the financial consequences of draft agreements. ${ }^{61}$ This threshold requirement for consultation with the bargaining parties is in fact a common requirement for any similar types of interventions by the authorities. ${ }^{62}$ Nonetheless, 'notwithstanding any opinion submitted by the financial authorities, the parties to collective bargaining should be able to conclude an agreement freely' ${ }^{63}$

The last point relates to the Committee of Experts' examination of the impact on the collective bargaining rights of public sector workers of economic and other grave crises (such as wars or natural disasters), and the economic stabilisation policies of different countries. ${ }^{64}$ These policies have included, inter alia, measures to cut or freeze wages, or to confine rises within certain limits, or prohibit outright the indexation of wages to the cost of living, thereby limiting voluntary collective bargaining and the autonomy of the bargaining parties. ${ }^{65}$ The consistent position of the Committee of Experts in addressing such problems has been that collective agreements must be respected and that limitations on the content of future agreements, particularly in relation to wages, imposed in these circumstances are admissible only on the following two conditions:

\footnotetext{
${ }^{60}$ ILO, Freedom of Association — 2006 Digest, above n 29, [1036].

${ }^{61}$ Ibid [1037].

${ }^{62}$ See generally, ILO, Collective Bargaining in the Public Service: A Way Forward, above n 3, Part II.

${ }^{63}$ ILO, Freedom of Association - 2006 Digest, above n 29, [1037]; Gernigon, Odero and Guido, above n 7, 49-50, quoting from the International Labour Organisation, Freedom of Association - Digest of Decisions and Principles of the Freedom of Association Committee of the Governing Body of the ILO (November 1996). .

${ }^{64}$ ILO, Collective Bargaining in the Public Service: A Way Forward, above n 3, $123-4$.

${ }^{65}$ Ibid.
} 
1. that they have been subject to prior consultations with workers' and employers’ organisations; and

2. that they meet the following conditions: '(i) they are applied as an exceptional measure; (ii) they are limited to the extent necessary; (iii) they do not exceed a reasonable period; and (iv) they are accompanied by safeguards to protect effectively the standard of living of the workers concerned, in particular those who are likely to be the most affected. ${ }^{, 66}$

\section{DisPUTE RESOLUTION AND THIRD PARTY INTERVENTION}

\section{A The Voluntary Nature of Bodies for the Resolution of Collective Bargaining (Interests) Disputes}

As mentioned above, the ILO's principles on collective bargaining clearly favour dispute settlement procedures whereby the parties themselves find a solution to their dispute. The ILO acknowledges that governments, and finance ministries in particular, have a legitimate interest in the impact of public sector wage determinations; accordingly, 'there must be some discourse between political and labour relations mechanisms' ${ }^{67}$ Further, if a breakdown in public sector bargaining leads to a disruption in the delivery of public services, the authorities will obviously be interested parties. Nonetheless, if the labour relations system is to be effective in achieving its objectives, including its goals of public sector efficiency and equity, then it 'must be given space to do its work'.68

Accordingly, the ILO’s supervisory bodies have considered that, although third party mechanisms such as conciliation and/or arbitration can facilitate collective bargaining, legislation establishing procedures to facilitate bargaining and settle collective bargaining disputes must respect the autonomy of the parties. ${ }^{69}$ The Committee of Freedom of Association has emphasised that, whatever type of machinery is implemented, its first objective should be to encourage, by all possible means, free and voluntary collective bargaining,

\footnotetext{
${ }^{66}$ Ibid 124; ILO, Freedom of Association, above n 58, [260].

${ }^{67}$ ILO, Manual on Collective Bargaining, above n 23, 11-12.

${ }^{68}$ Ibid 11.

${ }^{69}$ ILO, Collective Bargaining in the Public Service: A Way Forward, above n 3, 157 [389], referring to the ILO's Committee of Freedom of Association. As noted under heading IV, the Committee of Experts on the Application of Conventions and Recommendations has made comments to the same effect.
} 
'while establishing a legal framework and an administrative structure to which they may have recourse, on a voluntary basis and by mutual agreement, to facilitate the conclusion of a collective agreement' ${ }^{70}$ It points out that the mere intervention of a neutral, independent third party, in which the parties have confidence, is often enough to break a stalemate which the parties would be unable to resolve themselves. ${ }^{71}$ The Committee notes that the provisions of Convention No 154 are of particular relevance in this context, as are the Voluntary Conciliation and Arbitration Recommendation, 1951 (No 92), in particular its reference to the two essential characteristics of the conciliation and arbitration machinery: the joint nature of such machinery (including equal representation of employers and employees); and voluntary recourse to procedures, which should be free of charge and expeditious. ${ }^{72}$

The supervisory bodies admit voluntary conciliation and mediation (as well as voluntary arbitration) in accordance with the provisions of the Voluntary Conciliation and Arbitration Recommendation No 92 which states that: 'provision should be made to enable the procedure to be set in motion, either on the initiative of any of the parties to the dispute or ex officio by the voluntary conciliation Authority'. ${ }^{73}$ In other words, if these mechanisms are accepted by the parties, they pose no problem to the principles of collective bargaining since their role is to support bargaining. However, if conciliation and mediation are systematically imposed by law, they may, 'after a certain time and in certain cases', hamper or even restrict the parties' collective bargaining autonomy to varying degrees, depending on the nature of the process and how it is regulated. ${ }^{74}$

\section{B The Independence and Impartiality of Procedures and Confidence of Parties}

It also follows from article 8 of Convention No 151 that when dispute resolution procedures are established by law (rather than by the parties themselves), those procedures must be sufficiently independent and impartial to ensure the

\footnotetext{
${ }^{70}$ ILO, Freedom of Association, above n 58, [247] (emphasis in original).

${ }^{71}$ Ibid.

72 Ibid. The Committee of Experts has similarly emphasised that in order for such machinery to be effective in promoting bargaining, it must be autonomous; accessible; informal; expeditious; and consensual - so as to ensure the confidence of the parties: ILO, Collective Bargaining in the Public Service: A Way Forward, above n 3, 172-3, 209.

${ }^{73}$ Gernigon, Odero and Guido, above n 7, 44.

${ }^{74}$ ILO, Collective Bargaining in the Public Service: A Way Forward, above n 3, 171 (emphasis added).
} 
confidence of the parties. ${ }^{75}$ The Committee of Experts observes that, with a view to guaranteeing these elements, many legal systems grant dispute resolution bodies a large degree of autonomy from the public authorities. ${ }^{76}$ The Committee notes that in some cases, this autonomy is sought when setting criteria for the establishment of these bodies: for example, by providing for an equal number of employee and employer representatives, and independent members. ${ }^{77}$ In others, provision is made (for example) for independent conciliators designated jointly by the parties, or chosen by both chambers of parliament from a pool of labour law experts. ${ }^{78}$

The Committee of Experts emphasises, however, that whether a system can guarantee the impartial and independent resolution of bargaining disputes in accordance with Convention No 151, depends on its capacity to ensure the confidence of the parties in practice. The Committee of Experts accordingly underlines the fact that a system for the resolution of public sector collective bargaining disputes which provides for conciliation, mediation or arbitration bodies that are administrative in nature and composition does not meet the requirements of the Convention. It fails to meet Convention requirements with regard to the independence and impartiality of procedures, and their ability to secure the confidence of the parties. ${ }^{79}$

\section{Role of Arbitration in the Resolution of Bargaining Disputes}

The ILO regards arbitration as the next step after mediation in the 'dispute resolution chain', ${ }^{80}$ and as a reserve measure. In voluntary arbitration the parties, realising that their own efforts will not resolve a bargaining dispute,

\footnotetext{
75 Ibid 173. The ILO, while not itself prescribing a specific model for such procedures, notes the variety of approaches applied internationally, including the use of specialised labour courts, ordinary courts and labour commissions, to name but a few.

${ }^{76}$ Ibid.

77 This is common practice in a number of police jurisdictions. See Ian McAndrew, 'An Examination of Police Pay Setting Systems with Particular Consideration of the Right to Strike and of Models of Arbitration' (Unpublished Briefing Paper Prepared for the New Zealand Police Association, NZ Mediators, 24 October 2006). In Australia, an example is the Northern Territory Police Arbitral Tribunal, whose membership consists of an independent chairperson, the Minister's nominee, and the Police Association's nominee.

${ }^{78}$ ILO, Collective Bargaining in the Public Service: A Way Forward, above n 3, 173.

${ }^{79}$ Ibid. The Committee of Experts has also underscored the importance of dispute settlement procedures and bodies (voluntary conciliation, mediation and arbitration) being designed appropriately to settle disputes fairly and speedily.

${ }^{80}$ See ILO, Manual on Collective Bargaining, above n 23, 188-9. Limitations of space prohibit a detailed discussion here of the relationship between conciliation, mediation and arbitration.
} 
voluntarily agree to place the issues dividing them before a neutral third party such as an individual arbitrator or arbitration board. The arbitrator is empowered - either via a collective agreement or by statute - to consider evidence and argument and then make a final, binding determination. ${ }^{81}$ The ILO points out that, while arbitration is often seen by all parties as a preferable alternative to the exercise of power as a method of breaking a bargaining stalemate, a particular advantage of voluntary arbitration is that the process will generally not be called into question precisely because it has been jointly agreed to. ${ }^{82}$

Voluntary arbitration is always legitimate and in full conformity with the ILO's principles of voluntary and free collective bargaining. This is not true, however, of compulsory arbitration, imposed either directly by law, or by administrative decision or at the initiative of one party, except in specified circumstances. ${ }^{83}$ This is because compulsory arbitration can rob the collective bargaining process of its vitality and equity. It is, therefore, in the ILO's view, an option that must be approached with caution. ${ }^{84}$ The Committee of Experts points out that the expression 'compulsory arbitration' can give rise to a degree of confusion. If the term refers to the compulsory effects of arbitration resorted to voluntarily by the parties, this does not create a problem, since the parties should be deemed to accept a binding decision by an arbitrator or arbitration board that they have freely chosen. The real issue arises in the case of compulsory arbitration which the authorities may impose in a bargaining dispute - either at the request of one party or at their own initiative - the effects of which are compulsory for the parties. ${ }^{85}$

The ILO supervisory bodies have stated repeatedly that the use of compulsory arbitration is not easily reconcilable with the principle of voluntary bargaining established by Convention No $98{ }^{86}$ Depending on the model, the public administrative or legislative authorities, either intervening on their own initiative or on the request of one of the parties to a dispute, may be: authorised

\footnotetext{
${ }^{81}$ Ibid 118. This accords with ILO, Voluntary Conciliation and Arbitration Recommendation 1951 (No 92), (International Labour Conference $-34^{\text {th }}$ Session, 1951) art 6, which provides: 'If a dispute has been submitted to arbitration for final settlement with the consent of all parties concerned, the latter should be encouraged to abstain from strikes and lockouts while the arbitration is in progress and to accept the arbitration award.'

${ }^{82}$ Ibid 120.

${ }^{83}$ ILO, Collective Bargaining in the Public Service: A Way Forward, above n 3, 180. The specified circumstances referred to are discussed below.

${ }^{84}$ ILO, Manual on Collective Bargaining, above n 23, 124.

${ }^{85}$ ILO, Collective Bargaining in the Public Service: A Way Forward, above n 3, 181.

${ }^{86}$ Gernigon, Odero and Guido, above n 7, 27-8.
} 
either to endeavour to resolve the dispute themselves; to submit the dispute to designated bodies (such as a conciliation board or arbitral body); or, to refer the dispute to the judicial authorities. In the opinion of the Committee of Experts, each of these approaches raises problems of compatibility with ILO standards. ${ }^{87}$ In contrast, certain legal systems provide that, once conciliation between the parties has been unsuccessful, the dispute is referred to a designated independent body entrusted with issuing recommendations which, after a certain period, become enforceable if neither party has challenged them. The Committee regards this type of model as compatible with the relevant standards, as long as the legal period referred to is reasonable. ${ }^{88}$

In any event, the supervisory bodies allow recourse to compulsory arbitration as an exception to bargaining in certain specified circumstances, particularly where the model is the product of consent between the parties ${ }^{89}$ Importantly for present purposes, one of these exceptions is the case of bargaining disputes involving essential services employees in the strict sense of that term. ${ }^{90}$ As will be seen below, the Committee of Experts permits compulsory arbitration for these particular employees, to counterbalance the restriction or removal of the right to strike in support of bargaining. ${ }^{91}$

Compulsory arbitration is especially prevalent amongst police and other emergency service workers as a trade-off for the right to strike. ${ }^{92}$ The rationale for the availability of compulsory arbitration in this context is two-fold: to safeguard the workers' industrial interests; and to protect the community from the harmful effects of workplace disputes. In the view of the ILO, a good example of the policy considerations at stake is captured in the following provision from a police and fire arbitration statute in the United States:

It is the public policy of this State that in public police and fire departments, where the right of employees to strike is by law prohibited, it is requisite to the high morale of such employees and the efficient operation of such

\footnotetext{
${ }^{87}$ ILO, Collective Bargaining in the Public Service: A Way Forward, above n 3, 181-2.

${ }^{88}$ Ibid 182.

${ }^{89}$ ILO, Manual on Collective Bargaining, above n 23, 124.

90 The others being in cases involving public administration; in the event of a national emergency; or where, after protracted and fruitless negotiations, it is obvious that the stalemate will not be resolved. Compulsory arbitration is also allowable where it is provided for in a collective agreement as a process for the resolution of disputes: Gernigon, Odero and Guido, above n 7, 44.

${ }^{91}$ Even here, however, an important caveat is that arbitration should be performed by impartial bodies and the parties permitted to participate at all stages of the procedure: ILO, Manual on Collective Bargaining, above n 23, 125.

${ }^{92}$ See ILO, Public Emergency Services, above n 9, 101-2; McAndrew, above n 77.
} 
departments to afford an alternate, expeditious, effective and binding procedure for the resolution of disputes, and to that end the provisions of this [A]ct, providing for compulsory arbitration, shall be liberally construed. ${ }^{93}$

On the other hand, as noted earlier, the ILO has pointed out that, given that the blanket prohibition of strikes is less frequent than it was in the past in these areas of public service, it is worth considering the possibility of avoiding absolute bans on strikes. ${ }^{94}$ This concept, suggesting the need for a proportional analysis, is examined in the following sections.

\section{Strikes AND the WithdRAWAL OF SERVICES}

The right of unionised employees to strike through the peaceful withdrawal of services in order to defend their economic and social interests has been widely accepted as one of the pillars of the freedom to associate, along with the right to organise and the right to collectively bargain. ${ }^{95}$ The right is regarded by the ILO as an 'intrinsic corollary' to collective bargaining, and, as a general rule, also holds true for public sector collective bargaining. ${ }^{96}$ It has been described 'as an indispensable component of a democratic society', and has been 'justified as a countervailing force to the power of capital'.${ }^{97}$

ILO instruments do not expressly refer to the right to strike in support of collective bargaining. ${ }^{98}$ Nonetheless, the Committee on Freedom of Association and the Committee of Experts have long recognised the right to strike $^{99}$ as an essential means available to workers and their organisations for

93 ILO, Manual on Collective Bargaining, above n 23, 125, quoting from the Compulsory Arbitration of Labor Disputes in Police and Fire Departments Act 312 of 1969, 423 MCL (1969).

${ }^{94}$ ILO, Public Emergency Services, above n 9, 103.

${ }^{95}$ Lynk, above n 39, 9.

${ }^{96}$ ILO, Freedom of Association - 2006 Digest, above n 29, [523]; ILO, Manual on Collective Bargaining, above n 23, 133.

${ }^{97}$ Fumane 'Malebona Khabo, 'Collective Bargaining and Labour Disputes Resolution — Is SADC Meeting the Challenge?' (Issues Paper No 30, International Labour Organisation Sub-Regional Office for Southern Africa, March 2008) $17<$ http://www.ilo.org /public/english/region/afpro/harare/download/issues_paper_30.pdf>; citing an earlier source quoting from Sir Otto Kahn-Freund and Bob Hepple.

98 The right to strike is expressly referred to in the International Covenant on Economic, Social and Cultural Rights via art 8(1)(d), as part of its umbrella of fundamental human rights. See Shae McCrystal, The Right to Strike in Australia (Federation Press, 2010) ch 2.

${ }_{99}$ The principles of the two bodies contain no set definition of strike action; however, certain types of strike action falling short of total work stoppages (occupation of the workplace, picketing, 'glow slows' or 'working to rule' strikes), have been accepted by the Committee on 
the protection of their interests. McCrystal explains that the Committee of Freedom of Association recognises the right to strike as a component of the principles of freedom of association as expressed within ILO standards. ${ }^{100}$ Furthermore, for those Member States that have ratified Convention No 87, the right is taken by the Committee of Experts and the Committee on Freedom of Association to be a component of the express protections of trade union freedoms under the Convention. ${ }^{101}$

The ILO has explained that the reason for regarding the right to strike as an integral part of collective bargaining is that, without it, 'bargaining risks being inconsequential — a dead letter'. ${ }^{102}$ According to the ILO, industrial action (including, inter alia, all forms of work stoppages, go-slows and lockouts) is the ultimate weapon in persuading the parties to bargain:

Industrial action, or the threat of industrial action, plays a key part in an effective bargaining process. Where conflicting interests need to be reconciled, knowing that the other party has the capacity and the right to exercise power helps focus the negotiators. This obliges them to take the other party seriously and reach a compromise settlement. In this important sense, industrial action is functional to collective bargaining. ${ }^{103}$

However, industrial action comes at an obvious price: to workers, to employers, to governments and to the broader community. This is especially so in the public sector, where disruptions to social services will nearly always adversely affect the public. Accordingly, the right to strike should be used only as a last resort when collective bargaining and existing third party mechanisms have been unsuccessful. ${ }^{104}$ It is also true that, in practice, the right is regulated by

\footnotetext{
Freedom of Association, provided they are conducted peacefully: Bernard Gernigon, Alberto Odero and Horacio Guido, ILO Principles Concerning the Right to Strike (1 January 2000) International Labour Organisation, $44<$ http://www.ilo.org/wcmsp5/groups/public/--ed_norm/---normes/documents/publication/wcms_087987.pdf>.

${ }^{100}$ McCrystal, above n 98, 22-3.

${ }^{101}$ Ibid 23.

${ }^{102}$ International Labour Organisation, 'Your Voice at Work: Global Report under the Follow-up to the ILO Declaration on Fundamental Principles and Rights at Work' (Report, International Labour Organisation, 25 May 2000) [101] <http://www.ilo.org/wcmsp5/ groups/public/---dgreports/---dcomm/---publ/documents/publication/wcms_publ_9221115046 _en.pdf> ('Your Voice at Work'), quoted in Lynk, above n 39, 10.

103 ILO, Manual on Collective Bargaining, above n 23, 33.

${ }^{104}$ ILO, 'Your Voice at Work', above n 102, [101]. The Voluntary Conciliation and Arbitration Recommendation 1951 (No 92) encourages parties who have agreed to submit to conciliation and arbitration to desist from striking while these processes are on foot ([4], [6]) and indicates that none of its provisions may be construed as 'limiting, in any way whatsoever, the right to strike ([7])'
} 
procedural and other limitations in many jurisdictions; ${ }^{105}$ in particular, many jurisdictions limit the capacity of 'essential services' and other public sector workers to engage in industrial action. ${ }^{106}$ On the other hand, according to the ILO, the fact that strikes, by definition, take place in conflict situations and may cause major inconvenience should not detract from the obligation to respect and safeguard the principles on which they are based. ${ }^{107}$

The point is increasingly stressed that public emergency services strikes, in particular, inflict more harm on the community than the employer, interrupting essential services which the state provides to the community. ${ }^{108}$ In this context, strikes and other forms of industrial action may simply be unacceptable. Accordingly, while the right to withdraw services in pursuit of bargaining is well established, ILO standards provide that this right does not encompass essential services whose interruption would threaten the life, personal safety or health of all or part of the population. ${ }^{109}$ These workers may be denied the possibility of engaging in industrial action, provided they have access to adequate compensatory safeguards. However, this has not prevented certain countries ${ }^{110}$ from maintaining the right to strike even in relation to the public services, the aim being to keep the bargaining dynamic alive even in this sensitive employment area. ${ }^{111}$

In their various decisions and commentaries, the two ILO supervisory committees have established a substantial body of principles regarding how the right to strike may be exercised. As a core feature of the freedom to associate, the right to strike is to be made available to all private and public

\footnotetext{
105 The Committee of Freedom of Association allows governments to legislate reasonable prerequisites for a lawful strike, such as requirements for conciliation and arbitration, strike notice, secret ballots and a majority vote. See ILO, Freedom of Association - 2006 Digest, above $n$ 29, [547] et seq.

${ }^{106}$ Breen Creighton, William J Ford and Richard J Mitchell, Labour Law: Text and Materials (Law Book Co, $2^{\text {nd }}$ ed, 1993) 1148. In its Public Emergency Services report, the ILO identifies only a handful of countries where police officers have a right to engage in industrial action in support of bargaining: above n 9, 102-3.

${ }^{107}$ ILO, Your Voice at Work, above n 104, [101].

${ }^{108}$ ILO, Public Emergency Services, above n 9, 100-1.

${ }^{109}$ ILO, Freedom of Association - 2006 Digest, above n 29, 581. Nor does the right, as a rule, encompass public servants engaged in the administration of the state, nor situations of national emergency. See McCrystal, above n 100, 33-6; and see also the discussion in the section that follows in Part VA, The Right to Strike in the Public Sector.

110 For example, Norway, Sweden, Denmark and Finland: ILO, Manual on Collective Bargaining, above n 23, 133.

${ }^{111}$ Ibid. As noted above, even in the context of public emergency services, including police services, blanket prohibition of strikes is nowadays less frequent than in the past: see text accompanying $n 9$.
} 
sector employees, except those working in the specifically designated occupations or circumstances noted above. The right to strike is not an absolute right. Nevertheless, because of the fundamental importance of the right to strike, the exceptions to it - including those relating to public and essential services - must be narrowly and precisely defined so that its purpose is not frustrated. ${ }^{112}$

\section{A The Right to Strike in the Public Sector}

To reiterate, because of the fundamental importance of the right to strike, prohibitions or restrictions on its exercise need to be justified. The Committee of Experts advocates that the right should be limited only in relation to: (i) public sector employees exercising authority in the name of the state; ${ }^{113}$ and (ii) public sector employees performing essential services within the strict meaning of the term. ${ }^{114}$ Furthermore, as a result of Article 9 of Convention No 87, ${ }^{115}$ the Committee on Freedom of Association has refused to find an objection to legislation which denies the right to strike to the armed forces and the police. ${ }^{116}$ As with the exceptions relating to collective bargaining, a government is not compelled to prohibit or restrict the freedom to strike for these categories of

\footnotetext{
112 Ibid 139; Lynk, above n 39, 13.

${ }^{113}$ Gernigon, Odero and Guido point out that the guidelines for determining the category of public sector worker who may be so excluded no longer emanate from national laws, but from the nature of the functions performed. Thus, while the right to strike of (for example) officials in ministries or those working in the administration of justice and the judiciary may be subject to restrictions or even prohibitions, certain public servants do not exercise authority in the name of the state and are therefore exempt from such restrictions. Examples of these are public servants in state-owned commercial or metropolitan transport undertakings or those employed in the education sector: Gernigon, Odero and Guido, ILO Principles Concerning the Right to Strike, above n 99, 448-9.

114 ILO, Manual on Collective Bargaining, above n 23, 139, citing the ILO Freedom of Association and Collective Bargaining: General Survey (Report No 3, International Labour Conference - 69 $9^{\text {th }}$ Session, 1983) [213]-[214] <http://www.ilo.org/public/libdoc/ilo/ P/09661/09661(1983-69-4B).pdf> ('General Survey'). See also ILO, Freedom of Association, above $n$ 58, [158]-[159].

115 Freedom of Association and Protection of the Right to Organise Convention, 1948 (Convention 87), art 9 provides that '[t]he extent to which the guarantees provided for in this Convention shall apply to the armed forces and the police shall be determined by national laws or regulations'.

116 Gernigon, Odero and Guido, 'ILO Principles Concerning the Right to Strike’, above n 99, 447. Once again, for present purposes, police officers are treated as being analogous to essential public sector employees: see above n 28 .
} 
public sector workers, but it would not be inconsistent with the ILO's standards on freedom of association for it to do so. ${ }^{117}$

As the ability to restrict strike action carries with it the potential for abuse, the Committee of Experts stresses that the determination of which public employees could have the right to strike restricted, or denied to them, must be exercised as a limited and confined exception to the general right. ${ }^{118}$ The Committee has noted that 'too broad [a] definition of the concept of public servant is likely to result in a very wide restriction or even a prohibition of the right to strike for these workers'. ${ }^{119}$ The exercise of restricting access to the general right must be minimal and proportional:

The principle whereby the right to strike may be limited or even prohibited in essential services would lose all meaning if national legislation defined these services in too broad a manner. As an exception to the general principle of the right to strike, the essential services in which this principle may be entirely or partly waived should be defined restrictively: the Committee therefore considers that essential services are only those the interruption of which would endanger the life, personal safety or health of the whole or part of the population. ${ }^{120}$

Drawing on the jurisprudence and standards established by the two Committees, the application of the right to strike in the public sector can be characterised as falling into three distinct categories:

1. The broad and general right to strike, which is the governing rule;

2. A partial and restricted right to strike; and

3. An outright prohibition on the right to strike. ${ }^{121}$

Lynk makes the important point that, even in a public sector context, a government does not, according to ILO standards, have a policy choice as to which one of these categories it might wish to apply. Given that the withdrawal of services is fundamental to the freedom of association, a decision to restrict or prohibit the freedom to strike must be made in a manner that is faithful to the protection and guarantee of any significant right. Restrictions or prohibitions

\footnotetext{
${ }^{117}$ Lynk, above n 39, 14.

${ }^{118}$ Ibid; McCrystal, above n 98.

${ }^{119}$ ILO, 'Freedom of Association', above n 58, [158].

${ }^{120}$ Ibid [159]. See further, ILO, Freedom of Association - 2006 Digest, above n 29, [581].

${ }^{121}$ Lynk, above n 39, 15.
} 
on the freedom to strike must be plainly justifiable by the government, and strictly proportional to the degree of reasonable and probable danger to the life, personal safety or health of the whole or part of the population. ${ }^{122}$

\section{B The Right to Strike and Essential Public Services}

For the reasons noted above, namely the potential abuse of the ability to place restrictions on strikes, the term 'essential' is narrowly defined, encompassing only those services where the withdrawal of labour would result in 'a clear and imminent threat' to the life, personal safety or health of the whole or part of the population. ${ }^{123}$ Obviously, police and other public emergency services would be legitimate essential services under this definition.

However, the Committee on Freedom of Association has confirmed that the concept of essential services in the strict sense is not absolute. Its meaning depends largely on a country's particular circumstances. Further, a nonessential service (for example, water supply) may become essential if a strike lasts beyond a certain time or extends beyond a certain scope, thus endangering the life, personal safety or health of the whole or part of the population. ${ }^{124}$

According to ILO standards as derived from the jurisprudence of the supervisory bodies, a government is clearly entitled to legislate for restrictions on, or even the prohibitions of, the right to strike for essential public services employees. However, in order to comply with these standards, a government would have to ensure that:

(i) the public services that are targeted for the withdrawal of services genuinely meet the definition of essential services in its strict and proper sense;

(ii) the guiding test for the restriction or prohibition of the right to strike would be based on the minimal and proportional analysis;

(iii) the first permissible exception to the broad and general right to strike that is to be explored would be a partial and restricted right to strike;

(iv) the scope for a partial and restricted right to strike is to be drawn as purposively as possible in order to establish the minimum amount [sic] of

\footnotetext{
122 Ibid.

${ }^{123}$ McCrystal, above n 98, 34, citing ILO, 'Freedom of Association', above n 58, [159]; and ILO, Freedom of Association - 2006 Digest, above n 29, [581].

${ }^{124}$ ILO, Freedom of Association - 2006 Digest, above n 29, [582].
} 
services that can be offered during a strike that are sufficient to avoid endangering the life, personal safety or health of the whole or part of the population, while allowing for as comprehensive an exercise of the right as possible in the circumstances; ${ }^{125}$

(v) a partial and restricted right to strike that compels an unnecessarily broad number of employees to continue to work and leaves only a relatively small number of employees with the ability to strike would make the exercise of the right futile, and the right to collectively bargain a hollow guarantee;

(vi) in determining the appropriate level of services for a partial and restricted strike, provision is to be made for the meaningful involvement of the trade union(s) to establish the appropriate levels;

(vii) ... if it is genuinely determined that even a partial and restricted strike would nevertheless endanger the life, personal safety or health of the whole or part of the population based on the minimal and proportional analysis, then the right to strike can be prohibited. ${ }^{126}$

Furthermore, both the Committee of Experts and the Committee on Freedom of Association have recognised that, where essential service employees are restricted or indeed prohibited from exercising the right to strike, they should be afforded appropriate guarantees to compensate for these restrictions. ${ }^{127}$ According to the Committee of Experts:

If strikes are restricted or prohibited in the public services or in essential services, appropriate guarantees must be afforded to protect workers who are thus denied one of the essential means of defending their occupational interests. Restrictions should be offset by adequate impartial and speedy conciliation and arbitration procedures, in which the parties concerned can take part at every stage and in which the awards should in all cases be binding on both parties. Such awards, once rendered, should be rapidly and fully implemented. ${ }^{128}$

${ }^{125}$ In this regard, the Committee of Experts has said that such minimum service arrangements would be justified only where this does not 'call into question the right to strike of the large majority of workers': ILO, Freedom of Association, above n 58, [162]. See further, ILO, Freedom of Association - 2006 Digest, above n 29, [607] and the discussion below in relation to the establishment of a minimum service.

126 This summary is drawn directly from Professor Lynk’s expert affidavit, above n 39, 16-17.

127 See ILO, Freedom of Association - 2006 Digest, above n 29, [595]-[603]; ILO, Freedom of Association, above n 58, [164].

${ }^{128}$ ILO, General Survey, above n 114, [214]. See also, ILO, Freedom of Association, above n 58, [164]; ILO, Freedom of Association - 2006 Digest, above n 29, [595]-[596]. Regarding the 
An alternative approach to strikes in essential services is to require the maintenance of a minimum level of service during any strike, in which case trade unions should, along with the employers and public authorities, be able to participate in defining that minimum service. ${ }^{129}$ The Committee of Experts has proposed that, in order to avoid harms which are either irreversible or out of all proportion to the interests of the parties to a dispute, as well as damages-to third parties, governments could avoid outright bans on strikes in essential public services by adopting this approach even to the public emergency services. ${ }^{130}$ In the Committee's view, such a service should meet at least two key requirements. First, it must genuinely be a minimum service, that is, 'one which is limited to the operations which are strictly necessary to meet the basic needs of the population or the minimum requirements of the service, while maintaining the effectiveness of the pressure brought to bear'. Second, workers' organisations should be able, if they wish, to participate in determining such a service, along with employers and the public authorities. ${ }^{131}$

Finally, it was noted earlier that the concept of essential services in the strict sense depends largely on a country's particular circumstances. As a result, the Committee of Experts has stated that it is neither possible nor desirable to compile a 'complete and fixed list' of essential services. ${ }^{132}$ Nonetheless, the Committee on Freedom of Association's Digest provides, in a general sense, an illustrative list of essential services. These are the services provided by the hospital sector; electricity services; water supply services; telephone services; services provided by the police and armed forces; fire-fighting services; prison services; the provision of food to school-age students, and the cleaning of schools; and air traffic control services. ${ }^{133}$ Once again, while these illustrations are not exhaustive, police and other public emergency services would be likely to be considered legitimate essential services under this approach.

\footnotetext{
requirement of impartiality, see ILO, Freedom of Association - 2006 Digest, above n 29, [598]; Gernigon, Odero and Guido, ILO Principles Concerning the Right to Strike, above n 99, 453.

${ }^{129}$ ILO, General Survey, above n 114, [215]; Breen Creighton, 'Enforcement in the Federal Industrial Relations System: an Australian Paradox' (1991) 4(3) Australian Journal of Labour Law 197, 202.

${ }^{130}$ ILO, Public Emergency Services, above n 9, 103. See also, ILO 'Joint Meeting on Conditions of Employment and Work of Fire-fighting Personnel' (Report, International Labour Organisation, 9-16 May 1990) 8-9 ('Joint Meeting').

${ }^{131}$ ILO, Freedom of Association, above n 58, [161].

132 Ibid [159]; McCrystal, above n 98, 34.

${ }^{133}$ See further, ILO, Freedom of Association — 2006 Digest, above n 29, [585], [587].
} 


\section{The Australian Case on Collective Bargaining AND THE RIght to Strike IN ESSENTIAL SERVICES}

This part of the article compares Australian law with international labour standards with respect to essential public sector employees in the context of a strike in support of bargaining. Specifically, it analyses legislation governing essential service employees and police officers operating under Australia's Fair Work Act 2009 (Cth); and assesses these provisions in the light of the prevailing jurisprudence of the ILO.

Australia's traditional system of regulating labour relations disputes through compulsory arbitration as an alternative to collective bargaining and the right to strike did not treat essential services as a special case. Essential service employees were subject to prohibitions on striking, but had access to the same binding arbitration processes as other employees. ${ }^{134}$ This model would likely have met the ILO requirement that essential services workers denied the right to strike have access to rapid and impartial mechanisms for the resolution of bargaining disputes. ${ }^{135}$ However, major reforms in 1993 introduced a new principal object to the then Industrial Relations Act 1988 (Cth), making bargaining the dominant wage determination process, and introducing a right to strike. The shift to collective bargaining limited the scope for compulsory arbitration. At the same time, the changes were accompanied by special provisions for essential services, enabling the federal industrial tribunal to remove the right to industrial action and substitute compulsory arbitration in the event of 'threatened danger' to the public. ${ }^{136}$

This position has continued virtually unchanged over the last two decades. The core objective of the current Fair Work Act is the achievement of productivity through enterprise-level collective bargaining premised on a limited right to strike. ${ }^{137}$ The Fair Work Act covers most Commonwealth (and Territory) public sector employees, including members of the Australian Federal Police (AFP), and most Victorian public sector employees, including members of the Victoria Police. However, the Act allows the national tribunal to remove the right to threatened or actual protected industrial action in key public interest situations,

\footnotetext{
${ }^{134}$ See generally Carol Fox, 'Collective Bargaining and Essential Services: The Australian Case' (1998) 40(2) Journal of Industrial Relations 277; and see also Carabetta, 'Fair Work' above n 27, 263.

${ }^{135}$ Creighton, above n 129.

${ }^{136}$ Fox, above n 134, 279, 281.

${ }^{137}$ Fair Work Act, s 3(f); Geoff Giudice, 'Keynote Address' (Paper presented at the 21st Annual Labour Law Conference, The University of Sydney Workplace Research Centre, 22 July 2013) 6-7.
} 
including in the context of bargaining negotiations involving essential services. Section 424(1) of the Act provides:

(1) The [Fair Work Commission] must make an order suspending or terminating protected industrial action for a proposed enterprise agreement that:

(a) is being engaged in; or

(b) is threatened, impending or probable;

if the Fair Work Commission is satisfied that the protected industrial action has threatened, is threatening, or would threaten:

(c) to endanger the life, the personal safety or health, or the welfare, of the population or of part of it; or

(d) to cause significant damage to the Australian economy or an important part of it. ${ }^{138}$

There can be little doubt that suspension or termination of protected industrial action under section 424 due to a threat to life or public safety is consistent with the restrictions allowed by the ILO with respect to essential services. ${ }^{139}$ However, section 424 attaches additional criteria to be used in determining restrictions to the right to strike, namely damage to the economy or an important part of it. These additional criteria may not be synonymous with a threat to the life, or the personal safety (among other things) of the whole or part of the population, unless the harm also amounts to a threat to public safety. ${ }^{140}$ Yet, as McCrystal points out, section 424 operates on the basis that economic

138 The effect of the removal of protected industrial action on these grounds is that the Commission must determine the dispute through compulsory arbitration via a workplace determination: Fair Work Act, ss 266-267.

${ }^{139}$ Note however the suggestion that the term 'welfare' may also go beyond the ILO standard: Australian Nursing Federation (ANF), Submission No 1 to Senate Education, Employment and Workplace Relations References Committee, Inquiry into the Conditions of Employment of State Public Sector Employees and the Adequacy of Protection of Their Rights at Work as Compared with Other Employees, 15 January 2013, 15 <https://senate.aph.gov.au/ submissions/comittees/viewdocument.aspx?id=ffee9a98-980a-4523-9035-ad571d331a44>.

While the following focuses on s 424 of the Act, it is also important to note that there are other provisions which do not comply with ILO standards, including s 424 (significant harm to a third party) and s 431 (significant damage to the Australian economy): see McCystal, above n 98, ch 7.

${ }^{140}$ Creighton, above n 129, 15; McCrystal, above n 98, 253-4. 
damage is, by itself, sufficient to restrict the right to strike, and this contravenes the standards of international law. ${ }^{141}$

In defining essential services, section 424 follows a 'consequences-based model' [needs explanation] for essential public services, as do provisions in many other jurisdictions. ${ }^{142}$ Moreover, section 424 adopts a 'hybrid' approach for essential services, incorporating both a no-strike model and an unfettered strike model. It seeks to reconcile the 'inherent tension' ${ }^{143}$ between, on the one hand, achieving a balance between employer and employee interests through the right to collective bargaining and the freedom to strike, and, on the other, the right to arbitration and the public interest in the maintenance of essential services. As noted, the ILO accepts that in practice an alternative approach to strikes in essential services may be to require the maintenance of a minimum level of service during a strike. Indeed, more recently, the Committee of Experts has expressed a preference for this option even in relation to police and other emergency services. ${ }^{144}$ The problem with section 424, however, is that it contains no pro-active measures for the protection of essential services during strikes. This is especially significant in the case of police officers and emergency services workers. While these workers are afforded an in principle right to protected industrial action in support of bargaining under the Act, ${ }^{145}$ there is little scope for them to engage in such action. For police officers, industrial actions that would generally qualify for protection would be limited to such activities as working-to-rule, bans on the giving of notices for speeding or traffic infringements, and the like. ${ }^{146}$ These actions place financial pressure on the employer without placing the community's safety or welfare at risk. Beyond this, however, it may be asked how access to protected action under

\footnotetext{
${ }^{141}$ McCrystal, above n 98. Observations of both ILO supervisory bodies in relation to Australia clearly confirm that economic damage of itself is not compatible with the standards of the ILO to limit the right to strike: at 254-5.

${ }^{142}$ See Bernard Adell, Michel Grant and Allen Ponak, Strikes in Essential Services (IRC Press, 2001). Under a consequences (or harm-based) approach, rather than legislation specifically naming certain services as essential, special laws may be invoked if industrial action is deemed by a tribunal to threaten particular consequences: ibid, drawing on Gillian Morris, Strikes in Essential Services (Mansell, 1986) 8.

${ }^{143}$ Lynk, above n 39, 54, referring to the academic literature on essential services.

${ }^{144}$ See ILO, Public Emergency Services, above n 9, 103. See also, ILO, Joint Meeting, above n 130.

145 In addition to a number of general limitations on the right to 'protected action' of all employees under the Fair Work Act (see below), there are doubts surrounding the scope of the 'protected action' provisions of the Act for police officers: see Carabetta, Fair Work, above $\mathrm{n}$ 27, 268-9.

${ }^{146}$ Such limited forms of industrial actions by police officers have generally been allowable in Australia, despite formal restrictions on industrial action: see Carabetta, Fair Work, above n 27, 263, n 68 .
} 
the Act can provide employees such as police officers with a right to engage in free bargaining, when by definition almost any industrial action by them would threaten public safety or welfare and so lead to a termination or suspension of the protected action. ${ }^{147}$

The Fair Work Act approach may be contrasted with the hybrid models of other jurisdictions, including various Canadian models, ${ }^{148}$ which allow the right to strike but require, before the current agreement expires, the designation of positions considered essential. Employees in such positions are prohibited from striking. Designation may occur via an 'essential services agreement' or arbitration. Moreover, once the agreement is finalised, most models allow for the union or either party to dispute the classification and number of essential services. ${ }^{149}$ The lack of such features (or similar arrangements) in the Fair Work Act means that the right to bargain and to strike may be compromised, and the question may be asked whether the Act should contain provisions requiring the parties in good faith to negotiate minimum service agreements. ${ }^{150}$ Aside from the added certainty that this would bring to bargaining, a further advantage, consistent with ILO standards, is that it would encourage consultation with trade unions regarding essential service designations, thereby promoting added social dialogue between the parties.

It is also important to note that the Fair Work Act contains a number of general restrictions on protected industrial action applicable to all employees. These are examined in detail by McCrystal in The Right to Strike in Australia, ${ }^{151}$ her analysis pointing to significant restrictions on access to protected action under the Act. These restrictions include limitations on the range of claims that may be pursued through strike action. They also include prohibitions on taking

${ }^{147}$ Cf Justice Roger Boland, 'Some Current Matters of Interest' (Paper presented at the Annual Conference of the Industrial Relations Society of NSW, Kiama, 18 May 2012) [26]. In presenting findings on the impact of the precursor provision to s 424 of the Fair Work Act?, Fox concludes that while the Commission had varied in its willingness to allow or to suspend/terminate bargaining, a key factor in determining the level of impact of the industrial action was the nature of the work involved: Fox, above n 134, 302.

${ }^{148}$ See Fox, above n 134, 279 for a useful summary of the various models used in Canada.

149 See further, Lynk, above n 39, 26-48; and see generally, Bernard Adell, Michel Grant and Allen Ponak, above n 142. Lynk explains that the idea of a Designation Model is to 'treat the provision of essential services as an enclave to be sheltered from the interplay of economic power [between the union and the employer]', and for this reason 'a third party ... is made responsible for deciding on the nature and extent of essential services should the union and employer be unable to agree': above n 39, quoting from Adell, Grant and Ponak, above n $142,10$.

${ }^{150}$ Where such measures are adopted under the current model, this is solely the product of private or self-regulation: Fox, above n 134, 302.

${ }^{151}$ McCrystal, above n 98. 
protected action on a broader range of social and economic interests. McCrystal argues that, when combined with the limitations under section 424, these restrictions make access to industrial action under the Act 'a privilege rather than a right [which] goes against the international labour law requirement to respect the right to strike'. ${ }^{152}$ It is important to appreciate that they apply to essential service employees and police officers in the same way as to other employees.

If essential service employees and police officers face such restrictions on their capacity to engage in industrial action, the question then is whether they are, as required by the ILO, afforded 'adequate, impartial and speedy conciliation and arbitration'. Again, this is all the more significant in the case of police officers, given the additional restrictions on their capacity to engage in legitimate strike action. ${ }^{153}$ The Fair Work Act offers some scope for compulsory arbitration in specified circumstances; including where the Fair Work Commission terminates protected industrial action under section 424. In general, however, the Act provides very limited scope for the compulsory arbitration of collective bargaining disputes. ${ }^{154}$ Limitations on the capacity of the Fair Work tribunal to resolve disputes involving police officers arise also by virtue of the exclusion of a range of matters from bargaining. ${ }^{155}$ These exclusions go beyond those applicable to other public employees under the Act ${ }^{156}$ and, combined with constraints on the right to strike, particularly disadvantage police officers in affected jurisdictions. Further, where no adequate alternative provisions have been put in place under the relevant Police Act, the exclusions have produced 'gaps' in the regulatory framework. ${ }^{157}$

Victoria is the only state, to date, to have referred its public sector employment powers to the Commonwealth, such that the Fair Work Act regulates the employment of all Victorian public sector employees. ${ }^{158}$ As a result, the

\footnotetext{
152 McCrystal, above n 98, 195-6.

153 See text accompanying n 145-151.

${ }^{154}$ Mark Bray and Andrew Stewart, 'From the Arbitration System to the Fair Work Act: The Changing Approach in Australia to Voice and Representation at Work' (2103) 34(1) Adelaide Law Review 21 <http://www.adelaide.edu.au/press/journals/law-review/issues/alr_34_1.pdf>.

155 The exclusions relate to appointment, transfer, conduct and various other operational matters. See Carabetta, Fair Work, above n 27, 271-5.

156 These exclusions, concerning (Victorian) State public sector employees operating under the Fair Work Act, apply by virtue of s 5 of the Fair Work (Commonwealth Powers) Act 2009 (Vic) and relate to appointment and redundancy matters, and matters pertaining to high-level officers.

${ }^{157}$ Carabetta, Fair Work, above n 27.

${ }^{158}$ For details, see Carabetta, Fair Work, above n 27.
} 
capacity of Victorian essential service employees and police officers to engage in industrial action is subject to the same restrictions. In addition, however, amongst the matters excluded from the Fair Work Act under Victoria's referral of public sector employment powers are directions given to public sector employees under that State's essential services or state of emergency legislation. ${ }^{159}$ So while essential service employees and police officers in Victoria have access (to the extent that they apply) to the protected action provisions of the Fair Work Act, those provisions may not prevent the employer from otherwise seeking to rely on these state laws where these employees are deemed to have engaged in unprotected action. ${ }^{160}$

Thus the Essential Services Act 1958 (Vic) enables the Governor-in-Council to declare that a state of emergency exists in relation to an 'essential service'. Such a declaration may be made where it appears that any action has been or is likely to be taken whereby an essential service is or is likely to be interrupted, dislocated or materially diminished and:

(a) the opportunity of persons (other than those by whom the action has been taken or is likely to be taken or has been threatened to be taken) to be gainfully employed in their usual occupations; or

(b) the health or safety of the public or any section of the public; or

(c) the maintenance of peace and good order in Victoria

is prejudiced or threatened or is likely to be prejudiced or threatened. ${ }^{161}$

It will be seen that, like section 424 of the Fair Work Act, the Essential Services Act uses a consequences-based approach to the definition of essential services. However, essential services are defined to include services such as the provision of transport, fuel, light, power or sewerage. ${ }^{162}$ Interestingly, the definition does not expressly refer to police or other emergency services, but

159 See Fair Work (Commonwealth Powers) Act 2009 (Vic), s 5(1)(h)-(k); Fair Work (Commonwealth Powers) Bill 2009, Explanatory Memorandum, 5. This provision clearly comprehends essential public sector employees, including police officers: Fair Work (Commonwealth Powers) Act 2009 (Vic) s 3(2).

${ }^{160}$ Further, to the extent that the Essential Services Act 1958 (Vic) relies on specific criminal as distinct from civil — remedies, any proceedings brought against employees or their trade unions under these provisions would not come within the scope of the immunity offered by $\mathrm{s}$ 415 of the Fair Work Act.

${ }^{161}$ Essential Services Act 1958 (Vic) s 4(1).

${ }^{162}$ Essential Services Act 1958 (Vic) s 3. Certain other state jurisdictions also have essential services provisions. See in particular the Essential Services Act 1988 (NSW) and the Essential Services Act 1981 (SA). See also the Vital State Industries (Works and Services) Act 1992 (Vic). 
does include 'any other service specified from time to time by the Governor in Council'. ${ }^{163}$ An order declaring services to be essential services would need to be made to enable the Minister to exercise a wide range of powers granted under section 5 of the Act. If a state of emergency were declared, the Minister may provide, operate, control, regulate and direct that service; including the terms and conditions upon which the service shall operate. ${ }^{164}$

The Committee of Experts has expressed a number of concerns about the Essential Services Act (and the essential services Acts of other state jurisdictions). In particular, the Essential Services Act definition of 'essential service' in section 3 (like the definition used in other states) appears to go beyond the strict meaning of that term as adopted by the ILO. ${ }^{165}$ Rather than confining the definition of essential service to those services whose interruption would endanger the life, personal safety or health of the population, the Essential Services Act definition encompasses the harm posed by industrial action to the opportunity of persons to be meaningfully employed, and the maintenance of peace and good order of Victoria. ${ }^{166}$ The Committee of Experts' concern extends also to the power vested in the Governor-in-Council by section 3(g) to declare any service essential, since the exercise of that power is based on the same expansive definition. ${ }^{167}$

The other major problem with the Essential Services Act is that the legislative focus is on the exercise of coercive powers by the courts or government to maintain services and to punish those withdrawing them. ${ }^{168}$ The legislation is not specific to labour relations, and, contrary to ILO principles of freedom of association, there is no adequate substitute protection for the loss of the right to strike in the form of compulsory conciliation or arbitration (or like) procedures. This may be contrasted with the position under the Essential Services Act 1988 (NSW), which (although similarly problematic in other respects) ${ }^{169}$ provides

\footnotetext{
163 Essential Services Act 1958 (Vic) s 3(g). Other state jurisdictions in Australia also omit to refer expressly to police officers, but do include other emergency services such as fire-fighting and ambulance services. See, for example, Essential Services Act 1988 (NSW) s 4.

${ }^{164}$ Essential Services Act 1958 (Vic) s 5.

165 The Committee of Experts itself has often queried the scope of the NSW essential services provisions, and expressed concern about the scope and effect of essential services provisions of other states, including Victoria's Essential Services Act. See Breen Creighton, 'The ILO and the Protection of Fundamental Human Rights in Australia' (1998) 22(2) Melbourne University Law Review 239.

${ }^{166}$ Essential Services Act 1958 (Vic) s 4(1)(a), (c).

${ }^{167}$ Cf Creighton, Ford and Mitchell, above n 106, [33.20], referring to an observation of the Committee of Experts regarding the Essential Services Act 1988 (NSW).

${ }^{168} \mathrm{Cf}$ Fox, above n 134, 280, referring to Australian state essential services provisions generally.

${ }^{169}$ See Creighton, above n 129.
} 
for the reference of disputes in essential services to the NSW industrial tribunal. ${ }^{170}$

Finally, as with the state essential services provisions, the Committee of Experts has repeatedly expressed concerns over sections $30 \mathrm{~J}$ and $30 \mathrm{~K}$ of the Crimes Act 1914 (Cth). ${ }^{171}$ While these provisions are rarely invoked, they can nevertheless be used as a basis for criminal proceedings against individuals who participate in, or otherwise organise, a wide range of industrial action in the Commonwealth public services, and the transport industry. ${ }^{172}$ It is of concern that the powers in sections $30 \mathrm{~J}$ and $30 \mathrm{~K}$ do not accord with the criteria set out by the ILO supervisory bodies with respect to essential services. ${ }^{173}$ Further, to the extent that sections 30J and 30K apply to essential public sector workers and the Australian Federal Police, ${ }^{174}$ there is again no adequate compensatory mechanism for the loss of the right to strike.

\section{CONCLUSIONS}

The focus of this paper has been labour standards which were adopted under the auspices of the ILO and which constitute the principal international influences on public sector collective bargaining. The ILO, through the work of its supervisory bodies, recognises that the right to voluntary free collective bargaining and the right to strike constitute essential elements of the freedom of association. The supervisory committees assert that these fundamental rights are to be construed broadly and purposively, and that exceptions must be applied narrowly.

In the public sector, the right to free collective bargaining and the freedom to withdraw services are to be given full effect, save in exceptional cases. Under

\footnotetext{
${ }^{170}$ Essential Services Act 1988 (NSW) s 115; Creighton, above n 129.

${ }^{171}$ See, for example, ILO, Observation (CEACR) concerning the Freedom of Association and Protection of the Right to Organise Convention, 1948 (No. 87) - Australia (Ratification: 1973), (International Labour Conference $-85^{\text {th }}$ Session, 1997) <http://www.ilo.org/dyn/norm lex/en/f?p=1000:13100:0::NO:13100:P13100_COMMENT_ID,P11110_COUNTRY_ID,P11 110_COUNTRY_NAME,P11110_COMMENT_YEAR:2149711,102544,Australia,1996>.

172 Creighton, Ford and Mitchell, above n 106, [33.14].

${ }^{173}$ See, for example, ILO, Direct Request (CEACR) concerning the Freedom of Association and Protection of the Right to Organise Convention, 1948 (No. 87) - Australia (Ratification: 1973), (International Labour Conference $-80^{\text {th }}$ Session, 1993) <http://www.ilo.org/dyn /normlex/en/f?p=1000:13100:0::NO:13100:P13100_COMMENT_ID,P11110_COUNTRY_I D,P11110_COUNTRY_NAME,P11110_COMMENT_YEAR:2117471,102544,Australia,199 3>.

${ }^{174}$ Crimes Act 1914 (Cth) ss 30J(2)(b), 30K(b)-(c).
} 
ILO standards, restrictions on, or the removal of, the general right of workers to collective bargaining, and the substitution of compulsory arbitration for that collective bargaining, can be imposed on certain groups of public sector workers, including police officers and members of the armed forces. However, these restrictions and substitutions are at the discretion of individual countries. Restrictions on, or the removal of, the general right to collective bargaining can likewise be justified in the case of truly essential public services, ${ }^{175}$ but must be compensated for by impartial and speedy conciliation and arbitration processes. Based on the particular characteristics of public services, 'special modalities' of application for collective bargaining are allowable in these public services. However, according to the ILO, exceptions must again be applied proportionately and narrowly, leaving 'significant room' for bargaining. They should also be preceded by social dialogue with the representative organisations of public servants.

The ILO's supervisory bodies have held that although third party mechanisms such as conciliation and arbitration can facilitate bargaining, any third party involvement must respect the autonomy of the parties. Whatever type of machinery is applied, its primary objective should be the encouragement of voluntary arrangements. The ILO has emphasised that where dispute resolution procedures are established not by the parties themselves but by law, those procedures must be sufficiently independent and impartial to ensure the confidence of the parties in practice. Further, the Committee of Experts has underscored the importance of voluntary conciliation, mediation and arbitration being designed appropriately to settle bargaining disputes fairly and speedily.

The supervisory bodies have repeatedly emphasised that the use of compulsory arbitration is not easily reconcilable with the principles of voluntary collective bargaining. However, recourse to compulsory arbitration as an exception to collective bargaining is allowable in specified circumstances, particularly where it is the product of consent between the parties. One of those circumstances is in the case of essential public services in the strict sense. A clear example is seen in approaches to collective bargaining in the public emergency services, including police services. Compulsory arbitration is often used in these essential areas of public service as a trade off to the right to strike, although even in this context the blanket prohibition of strikes is nowadays less frequent than in the past.

According to ILO standards, the freedom of public sector workers to strike can be limited in the case of essential public service employees, including police

\footnotetext{
${ }^{175}$ As noted, in ILO terms essential services are those 'the interruption of which would endanger the life, personal safety or health of the whole of part of the population.'
} 
officers, on a minimal and proportional basis; but this must be offset by adequate, impartial and speedy conciliation and arbitration mechanisms. However, again, a government is not compelled to prohibit the right to strike for these workers. Even in the case of police officers, the ILO has said that it is 'worth considering the possibility of avoiding a total ban on strikes in [these areas] by ensuring the maintenance of a minimum service', ${ }^{176}$ where trade unions participate in determining that minimum service along with employers and the public authorities. In the ILO's view, such arrangements not only align with workers' rights to social dialogue, but can also enhance managementemployee relations in these employment areas.

In Australia over the last two decades, essential public service employees and police officers coming within the federal jurisdiction have for the first time been afforded a limited right to industrial action as part of collective bargaining. The federal tribunal has been given special powers under the Fair Work Act to remove the right to strike and substitute compulsory arbitration where the community's health or safety is threatened. On one level, this provision is consistent with ILO restrictions in respect of essential services, and with the need to recognise a right to strike and the public interest in the maintenance of essential services. However, contrary to suggestions from the ILO and international solutions, ${ }^{177}$ as well as affording limited immunity from industrial action, the Act contains no formal measures for the maintenance of essential services. For police and other emergency services in particular, there is minimal scope for protected action and uncertainty surrounding the right to bargain. At the same time however, there is limited scope for compulsory arbitration a point that has been highlighted by a number of high-profile long running disputes. ${ }^{178}$

The Essential Services Act applies to essential services employees and police officers in Victoria whose employment conditions are regulated by the Fair Work Act. The Act is particularly problematic from an ILO-compliance perspective. Not only does it allow for an overly broad definition of essential services, but, as with similar provisions in other states, its focus is the exercise of coercive legal powers to maintain essential services. The Act provides no adequate compensatory measures for the loss of the right to strike, in the form of compulsory conciliation and arbitration procedures. Similar observations apply, as the ILO Committee of Experts itself has confirmed, in relation to

\footnotetext{
${ }^{176}$ ILO, Public Emergency Services, above n 9, 103. See further, the comments of the Committee of Experts in ILO, 'Joint Meeting', above n 130.

177 Such as the approach applied to essential services in a number of Canadian jurisdictions, for example.

${ }^{178}$ See Boland, above n 147.
} 
sections 30J and 30K of the Crimes Act 1914 (Cth), which clearly cover situations where industrial action is causing major social or commercial harm, or both.

The ILO has in more recent times paid increased attention to collective bargaining in the public services. In the various ILO review reports referred to in this paper, ${ }^{179}$ the ILO and its supervisory committees note a global expansion in bargaining in public services, and further 'democratisation' of labour relations even in emergency and police services. Yet ironically, while Australia's shift to a bargaining model premised on the right to strike has better aligned it with ILO standards vis-à-vis the private sector, ${ }^{180}$ the opposite is true for its essential public sector workers. It is also clear that international models are the result of greater debate concerning essential public employees than has occurred in Australia. ${ }^{181}$ This factor, together with the problems relating to ILO compliance in Australia, suggests that there is value in Australian policymakers and legislators examining international solutions for the regulation of essential public sector employees.

\footnotetext{
${ }^{179}$ ILO, Collective Bargaining in the Public Service: A Way Forward, above n 3; ILO, Manual on Collective Bargaining, above n 23; ILO, Public Emergency Services, above n 9.

180 Australia's previous system of compulsory arbitration had raised questions regarding compliance with the ILO's principles of freedom of association: Owens, Riley and Murray, above n 15, [2.3.2].

${ }^{181}$ Fox, above n 134, referring in particular to Canadian solutions.
} 